\title{
Benign Testicular Neoplasm
}

National Cancer Institute

\section{Source}

National Cancer Institute. Benign Testicular Neoplasm. NCI Thesaurus. Code C3612.

A non-metastasizing neoplasm that arises from the testis. Representative examples include benign Sertoli cell tumor, thecoma, and fibroma. 